\title{
Macroeconometric Assessment of Monetary Approach to Balance of Payments in a Small Open Economy: The Nigeria Experience
}

\author{
Atoi Ngozi Victor \\ Statistics Department, Central Bank of Nigeria (CBN), Abuja \\ Email: atoinv@gmail.com
}

\author{
Article History \\ Received: February 15, 2020 \\ Revised: March 10, 2020 \\ Accepted: March 17, 2020 \\ Published: March 20, 2020 \\ Copyright (C) 2020 ARPG \& \\ Author \\ This work is licensed under \\ the Creative Commons \\ Attribution International

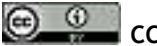 \\ BY: Creative Commons \\ Attribution License 4.0
}

\begin{abstract}
Monetary approach to balance of payment establishes a link between foreign reserve assets and money supply. This link is important for managing balance of payment disequilibrium through adjustment of monetary aggregates. This study relies on the (Polak, 1957;1997) monetary model with data from 2007:Q1 to 2018:Q4 to examine the link between monetary factors and balance of payment in Nigeria. To circumvent simultaneity, the reduced form coefficients of the structural form of the Polak model are estimated using Two Stage Least Squares (TSLS) technique, while the structural parameters are recovered from the estimated reduced form coefficients. The results are enriching and robust. The Johansen cointegration procedure suggests a long run relationship among the macroeconomic variables in the balance of payment function. The estimated balance of payment model reveals that domestic credit is statistically significant and negatively related to foreign reserve assets, implying that balance of payment is a monetary phenomenon in Nigeria. The velocity of money circulation and the marginal propensity to import are approximately 120 per cent and 14 per cent, respectively. The study therefore recommends that the monetary authority should consider the use of domestic credit for management of balance of payment disequilibrium. It is also pertinent to increase domestic credit to grow the economy since such action will marginally decrease external reserve assets through increase in import, however, the net effect will enhance the overall economy.
\end{abstract}

Keywords: Monetary approach; Balance of payment; Two stage least square; Simultaneous equation; Reduced form equation.

\section{Introduction}

There has been a long-standing debate on the link between balance of payments and monetary variables in monetary and international economics literature. Monetary theory of balance of payment has been applied in literature to examine this link with conflicting results. The arguments in literature have been influenced by developments in monetary theory and interpretations of monetary history (Akpansung, 2013). Other approaches to balance of payments management or adjustments exist - absorption and elasticities approaches (Salvatore, 2004), but monetary approach to balance of payment (MABOP) is becoming most appealing due to the inherent limitations of absorption and elasticities approaches in the management of balance of payments disequilibrium. These other approaches deal with the balance of payments problem through the current account of merchandise trade only, hence may not be the appropriate barometer for addressing balance of payment deficit. This current study focuses on the monetary approach (modern approach) to the balance of payments in Nigeria; as it looks beyond merchandise trade and incorporates the important role of financial assets (Melvin, 1992).

Since the deregulation of the Nigeria economy and the jettisoning of direct control of monetary policy in 1986, the monetary policy framework has evolved from the use of minimum rediscount rate (MRR) to monetary policy rate (MPR) as the anchor rate for short term money market rates. The MRR was intended to achieve balance of payments viability among others, but was replaced with MPR in December 2006 for lack of effectiveness. Under the current monetary policy framework, exchange rate policies have been put in place to manage external reserve assets and maintain the strength of the domestic currency with little recourse to use of monetary aggregates. Although the policy has some positive effects on international reserves and balance of payment (BOP), however, the attendant consequences of exchange rate depreciation/devaluation have implications on other sectors of the economy.

According to CBN (2015), the external reserves assets depleted by 17.4 per cent and the economy recorded BOP deficit of N1,150.13 billion in 2015. The 2015 report partly attributed the BOP disequilibrium to low inflow of forex caused by crash in the international oil prices. In managing the deficit, the forex market was further liberalised by closing the retail window of exchange rate transactions, introducing the investors and exporters (I\&E) window for foreign exchange (forex) transaction and removing forty-one (41) items that have potentials for domestic production from the list of items qualified for forex at the CBN forex window. Consequently, the annualised average exchange 
rate of the naira to the US dollar at the interbank foreign exchange window depreciated by 15.6 per cent to N196.49/US\$ in 2015 and further to N253.19/US\$ in 2016 (CBN, 2016), which spilled over to the real sector of the economy. The CBN annual report recorded that the year-on-year headline inflation rose above the single digit benchmark of 18.6 per cent at end-December 2016. Output contracted and unemployed labour force expanded by 1.5 and 13.9 per cent in 2016, against 2.8 and 10.4 per cent in 2015, respectively. Notwithstanding, the net domestic credit rose by 12.1 and 24.3 per cent to N21, 612.5 billion and N26,857.71 billion in 2015 and 2016, respectively (CBN, 2016).

The devaluation or depreciation of domestic currency to address disequilibrium in BOP while net domestic credit was on upward trajectory indicates that BOP management was more from the external sector than the monetary sector. However, in monetary theory, an inverse relationship between domestic credit and net foreign assets is established. In view of the obliterating effect of exchange rate devaluation/depreciation in managing BOP deficit, it becomes pertinent to understand the link between monetary variable and BOP in Nigeria. The earliest works on the assessment of MABOP in Nigeria were conducted when the country was not yet experiencing severe problem in the current account compared to the current level (Taiwo, 1991). Consequently, the results failed to support monetary approach for Nigeria, even when appropriate analytical technique - simultaneous equation was employed.

Recent studies in Nigeria confirmed that BOP disequilibrium is a monetary phenomenon. But they employed single equation ordinary least squares (OLS) estimation techniques that could not control for endogeneity (see (Imoughele and Ismaila, 2015; Onuchuku et al., 2018; Proso et al., 2016). Hence, the feedback effect with respect to domestic credit could not be identified in the equation since causality can only be unidirectional in single OLS equation. Thus, these studies may have suffered not only from simultaneous equation bias but inefficient estimates, since all the information available in the description of the system of equations are not utilized in their estimation procedure (Gujarati and Sangeetha, 2007; Koutsoyiannis, 1977; Pyndyck and Rubinfeld, 1976; Wooldridge, 2003). These gaps are corrected in this current study as it utilizes a small macroeconomic model in simultaneous equation form, by formulating the domestic and external sectors and their equilibrium conditions.

The broad objective of this study is to examine the link between monetary variable and balance of payment. The specific objectives are to (i) assess the effect of domestic credit on balance of payments and (ii) investigate the effect domestic credit on aggregate demand and total import.

Nigeria is one of the MINT countries deemed to show strong growth and provide high returns for investors in the years ahead. According to StatisticsTimes.com, Nigeria is the African most populous country with about $15.38 \%$ of the continent population and number seven in the world. The share of Nigeria GDP makes her the largest economy in the continent and $31^{\text {st }}$ biggest economy in the world in 2018. African Development Fund puts the Nigeria Trade balance at USD9,827.22 million compared to deficit USD123,546.34 million for the entire continent; and the current account balance as percentage of GDP is projected at $3.47 \%$ by end of 2020 placing her at number two position next to Botswana. Thus, this study for Nigeria is indispensable because of the important position it occupies in the economic space of the continent, as distortion in her balance of payment can affect international investors in the domestic economy, with strong implications on macroeconomic dynamics in the Sub Saharan Africa.

Thus, the outcome of the study provides useful policy advice to the monetary authority on the appropriateness of domestic credit for managing BOP. Financial analysts and international investors could also leverage on the insights from the study to minimize investment risks that could crystalize in the event of current account deficit in Nigeria.

\section{Review of Related Literature 2.1. Conceptual Review}

Total monetary aggregate (broad money supply) in an economy is made up of the Net Foreign Assets (NFA) and Net Domestic Assets (NDA). Conceptually, NFA is the difference in value of the assets that residents of a country own abroad, and the value of the domestic assets owned by non-resident. Foreign reserve assets is a significant component of NFA. The NFA also reflects movements in the BOP and can be expressed as a function of NDA. It captures all external transactions and measures the state of health of a domestic economy with the rest of the world.

Domestic assets is banking system's claims on resident sectors excluding resident sector claims on the banking system of an economy. The NDA is broken down into domestic credit (DC) and other item net (OIN) in the assets side of the banking system's balance sheet. By its mandate, monetary authorities control the level of DC through the use of monetary policy tools such as MPR, cash reserve requirements, open market operation in other to maintain a stable value of the domestic currency and achieve external stability objective. In other words, monetary policy stance to increase or decrease the cost or availability of domestic credit can affect the components of BOP.

The BOP is a systematic statistical record of economic transactions between the residents of a country and the rest of the world (non-residents) in a given period. From the IMF BOP Compilation manual version 5, BOP constitutes the current account balance $(\mathrm{CAB})$ and capital and financial account balance (KfAB). Any statistical discrepancy in $\mathrm{CAB}$ and $\mathrm{KfAB}$ is accommodated in the net errors and omissions component. A disequilibrium in $\mathrm{BOP}$, which is usually manifested in the $\mathrm{CAB}$ could be negative (debt transactions is higher than credit transactions) or positive (otherwise). The major component of $\mathrm{CAB}$ is the goods and services while that of $\mathrm{KfAB}$ is the foreign reserve assets.

Foreign reserve assets include foreign currency deposits and bonds. It measures the ability of a country to meet external obligations. Broadly speaking, it is made up of external assets such as foreign currencies, other assets denominated in foreign currencies, gold reserves, special drawing rights (SDRs) and IMF reserve positions. These 
constituents of foreign reserve assets are readily available to and controlled by a country's monetary authority for managing BOP disequilibrium through the forex market. Where the disequilibrium is negative, the adjustment can adversely impact on the international value of the domestic currency, leading to devaluation with attendant consequences.

\subsection{Theoretical Framework}

Although this study focuses on the monetary approach to management of BOP disequilibrium, however, other approaches are highlighted in this subsection to understand their inadequacies and justification for the monetary approach. The three approaches in literature include, elasticity, absorptive and monetary approaches.

\subsection{Elasticity Approach}

This approach is built on Marshallian partial equilibrium analysis and suggests that currency devaluation corrects current account deficit. The Marshallian elasticity analysis of devaluation is subject to criticisms (see (Dornbusch, 1971; Meade, 1951; Negishit, 1968) among which is that as a partial equilibrium analysis, it ignores cross-relations among relative goods prices and market forces. Again, it unrealistically assumes that improvement in trade balance due to devaluation is matched with saving in form of accumulation of foreign exchange reserves.

\subsection{Absorption Approach}

The absorption approach to balance of payment was built on the Keynesian national income framework by Alexander (1952). It focuses on changes in the real domestic income in determining the balance of payments but holds price constant while other variables are measured in real terms. Impliedly, the disequilibrium in BOP is factored in the consumption pattern of the domestic residents, which means that the current account position is directly related to relative changes in income and expenditure of the domestic economy. The major criticism of this approach is it totally ignores the capital account component of BOP.

\subsection{Monetary Approach}

The monetary theory was pioneered by the IMF Economist Polak (1957), Mundellr (1968), Argy (1969) and later expanded by Johnson and Frenkel (1976). The theoretical construct is centred on the premise disequilibrium in BOP can be corrected via an adjustment of monetary variables, mostly domestic credit (Akpansung, 1998). By implication, increase in domestic credit is assumed to lead to a growth in aggregate demand, including growth in the demand for imports. Furthermore, the approach hypothesises that supply of money is endogenous to the system by assuming a feedback in BOP disequilibrium via changes in foreign reserve assets to changes in the total monetary liabilities of monetary authority.

Johnson (1977), identified three distinguishing features of monetary approach. First, balance of payments disequilibrium is monetary problem, and should be treated with monetary models integrated in the real economy, rather than building models with real sector variables that obtain monetary behaviour through residuals of real behaviour. Second, stock equilibrium conditions and stock adjustment processes are required for analysing monetary imbalances because money is regarded as a stock and not a flow. Third, the expansion of domestic credit and the exchange of goods or assets for foreign exchange and foreign currency conversion into domestic currency are two sources of money, however, only the latter has impact on the balance of payments.

\subsection{Empirical Review}

A considerable amount of literature has empirically investigated the link between balance of payment and monetary variables in Nigeria. Most of the studies arrived at conflicting results. For instance, in a two stage least squares framework, Nyong and Obafemi (1995) employ a modified monetary approach to devaluation as propounded by Johnson and Frenkel (1976) and elaborated by Connolly and Taylor (1979) and found that expanding domestic credit aggravates the Nigeria's balance of payments position. They identified various factors responsible for the inapplicability of the monetary approach in the Nigerian context to include the structure of Nigeria's production, imports and exports coupled with instability in the macro-economy, political instability and unpropitious institutional environment. Similar results are obtained from related economies. Fleermuys (2005), examines the monetary approach to the Namibian balance of payments and found that some variables suggest the role of monetary approach but argued that the balance of payments is not a purely monetary phenomenon. Faiz (1989), tested the propositions of monetary approach to balance of payment theory for Pakistanand conclude that external reserves movements in Pakistan cannot be explained by monetary development.

Some of the earlier studies whose findings lend support for the theory in Nigeria include Akpansung (1998), who established the applicability of the monetary approach to the balance of payments in Nigeria using a TSLS estimation technique with relevant monetary variables. Empirical result shows that Nigeria's balance of payments has been dominated by monetary variables. The result confirmed that reserve accumulation is negatively related to the rate of growth of domestic credit. Jimoh (1990), investigates the relevance of the monetary approach to the Nigeria balance of payments using the data from 1960 to 1983 and finds support for the monetary approach to BOP in Nigeria.

The earlier empirical works that are contrary to the theoretical postulation in Nigeria attributed the outcomes to the fact that the country was just out from a regulated economy when exposure with the rest of the world was infinitesimal, hence current account deficit was not prominent see (Taiwo, 1991). Moreover, most of these were 
conducted before 2007, when the current monetary policy framework that adopted monetary policy rate as operating target was introduced.

In a more recent development, Bobai (2013) employ Johansen cointegration, vector error correction mechanism, impulse response function and variance decomposition to investigate the role of excess money supply in the balance of payment disequilibrium. The results confirm that BOP in Nigeria is not a purely monetary phenomenon. In other climes, Boateng and Ayentimi (2013) analyze balance of payment using the monetary approach in a single equation OLS framework and the result reveals that BOP imbalances in Ghana is not influence by only monetary variables. To effectively manage balance of payment account, the authors argue that government should not rely solely on monetary tools, give equal consideration to other policy variables. This result is consistent with the findings of Gulzar (2015); Mushendami et al. (2017).

On the other hand, Ajibola and Nwakanma (2013) apply annual data 1985 to 2011 to test the Polak model in Nigeria. The Johansen and Jesulius multivariate cointegration results provided support for long-run relationship among national income, net foreign assets, domestic credit and export. Within the period of study, which accommodated about four years of the current monetary policy framework, the velocity of money was found to be 300 percent, which they relate to the economy as being inflationary. The marginal propensity to import was estimated at 20 per cent. In a more related study, Tijani (2014) found a direct relationship between balance of payments and domestic credit, exchange rate and balance of trade using an OLS regression. The study argues that monetary measure is an effective mechanism for BOP management, but dependent on the policy mix of the monetary authority. The study further suggests that to stabilize BOP, monetary authority should implement expenditure reducing monetary policies through money supply and domestic credit to promote favourable BOP. Using similar econometric approach, Akonji and Olateju (2013), Imoisi et al. (2013), (Udude, 2015) and Proso et al. (2016) assert that monetary policy instruments affect balance of payment significantly. Hence, monetary policy can be applied to stabilise and improve the external sector in Nigeria.

More recent papers further examined the subject using a more dynamic model like auto regressive distributed lag (ARDL) and dynamic OLS (DOLS) models. Mukolu et al. (2017), assess the impact of monetary policy on balance of payments in Nigeria using ARDL cointegration technique. The result suggests that net trade, money supply and credit to private sector have short and long run significant impact on balance of payments. The study advocates for export diversification to enhance BOP, and also pushes for monetary authority to ensure that domestic money stock is consistent with macroeconomic objectives. Furthermore, Onuchuku et al. (2018) adopted a DOLS proposed by Stock and Watson (1993) to investigate the effect of monetary policy on BOP in Nigeria. The empirical findings suggest that the monetary variables are key determinants of BOP equilibrium in Nigeria. The paper recommends that monetary policy measures should target broad money supply, stable interest rate and exchange rate in order to control balance of payments deficits. By applying bound testing approach, Osisanwo et al. (2019) show that money supply and trade balance have positive impact on BOP in the long-run, where money supply is seen to have more impact. Conversely, domestic credit, exchange rate, inflation rate and gross domestic product suggest a negative impact on BOPs. To avoid distortion in price and the BOP position, the study deemed it expedient for the monetary authority to balance money supply and demand for money.

In sum, there seem to be more uniformity in the research outcomes that confirm monetary approach to balance of payment. However, it is evident that none of the reviewed studies for Nigeria conducted under the current monetary policy framework employed a robust econometric method to account for the feedback effect on monetary model for BOP. This raises some concern on the inference founded on the estimated coefficients because according to Kavous (2005) ordinary least squares estimates of the coefficients of the reserve flow equation do not constitute a reliable empirical test of the monetary approach to the balance of payments. Furthermore, the existing recent studies did not employed a macroeconomic model that reflect the goods and money market equilibrium. It is against this backdrop that this current study stands unique.

\section{Methodology}

\subsection{Sources of Data}

Quarterly data used in this study were obtained from the Central Bank of Nigeria Statistical Bulletin. The observation period ranges from 2007Q1 to 2018Q4. The study period was carefully chosen to accommodate the time of commencement of the use of monetary policy rate (MPR) as the anchor rate in the existing monetary policy framework.

\subsection{Description of Research Variables}

The variables considered in this study are nominal gross domestic product (Y), money supply (MS), total import (M) foreign reserve assets (F) domestic credit (D), export $(\mathrm{X})$ and capital inflows $(\mathrm{K})$. The variables are measured in trillions of Nigeria Naira in nominal terms.

\subsection{Model Specification}

As hypothesised in theoretical literature that increases in domestic credit have adverse effect on the balance of payments, we follow the Polak (1957), (Polak, 1997) and specify a macro system of equations to assess the importance of MABOP adjustment in Nigeria. We consider two behavioural equations and two equilibrium conditions, which constitute a simple version of the Polak Model.

The econometric form of Polak (1957), (Polak, 1997) monetary model is presented below:

$$
Y_{t}=\alpha+v M S_{t}+\mu_{1 t}
$$




$$
\begin{aligned}
& M_{t}=\beta+m Y_{t}+\mu_{2 t} \\
& F_{t}=F_{t-1}+X_{t}-M_{t}+K_{t} \\
& M S_{t}=D_{t}+F_{t}
\end{aligned}
$$

The parameters of the structural equations ( 1 and 2 ) cannot be estimated using OLS because of the problem of simultaneous equation bias. To circumvent this problem, we derive the reduced form of the model, which solves the system for the values of the endogenous variables in terms of the predetermined variables and the structural parameters.

We derive the reduced form of equation 3, by substituting equations (1) and (2) into it, which gives:

$$
\begin{array}{ll}
F_{t}=-\left(\frac{1}{1+m v}\right)\left[-(m \alpha+\beta)+F_{t-1}+X_{t}+m v D_{t}+K_{t}\right]+\epsilon_{1 t} & 5 \\
F_{t}=\pi_{1}+\pi_{2} F_{t-1}+\pi_{3} X_{t}-\pi_{4} D_{t}+\pi_{5} K_{t}+\epsilon_{1 t} & 6
\end{array}
$$

where $\pi_{i}$ are the reduced form coefficients used in recovering the structural coefficients. Comparing equations 5 and 6, we have:

$\pi_{1}=-(m \alpha+\beta)(1+m v)^{-1} ; \pi_{2}=\pi_{3}=\pi_{5}=(1+m v)^{-1} ;$ and $\pi_{4}=-m v(1+m v)^{-1}$

In this study, focus is on the importance equation 6 attaches to the relation between $D$ and $F$. From the equation 6 , the multiplier which measures the impact of an expansion or contraction of domestic credit on the balance of payments is:

$$
\frac{\delta F}{\delta D}=-\frac{m v}{1+m v}
$$

We derive the reduced form of equation 4 , by substituting equation (5) into it:

$$
\begin{array}{ll}
M S_{t}=\left(\frac{1}{1+m v}\right)\left[-(m \alpha+\beta)+F_{t-1}+X_{t}+D_{t}+K_{t}\right]+\epsilon_{2 t} & 8 \\
M S_{t}=\pi_{6}+\pi_{7} F_{t-1}+\pi_{8} X_{t}+\pi_{9} D_{t}+\pi_{10} K_{t}+\epsilon_{2 t} & 9
\end{array}
$$

Comparing equations 8 and 9 , we have:

$$
\pi_{6}=-(m \alpha+\beta)(1+m v)^{-1} ; \text { and } \pi_{7}=\pi_{8}=\pi_{9}=\pi_{10}=(1+m v)^{-1}
$$

We derive the reduced form of equation (1), by substituting equation (8) into it:

$$
\begin{array}{lr}
Y_{t}=\left(\frac{v}{1+m v}\right)\left[(\alpha / v-\beta)+F_{t-1}+X_{t}+D_{t}+K_{t}\right]+\epsilon_{3 t} & 10 \\
Y_{t}=\pi_{11}+\pi_{12} F_{t-1}+\pi_{13} X_{t}+\pi_{14} D_{t}+\pi_{15} K_{t}+\epsilon_{3 t} & 11 \\
\pi_{11}=(\alpha-v \beta)(1+m v)^{-1} \text {; and } \pi_{12}=\pi_{13}=\pi_{14}=\pi_{15}=v(1+m v)^{-1}
\end{array}
$$

Comparing equations 14 and 15 , we have:

Finally, we derive the reduced form of equation (2), by substituting equation (10) into it:

$$
\begin{aligned}
& M_{t}=\left(\frac{m v}{1+m v}\right)\left[\left(\frac{\alpha}{v}+\frac{\beta}{m v}\right)+F_{t-1}+X_{t}+D_{t}+K_{t}\right]+\epsilon_{4 t} \\
& M_{t}=\pi_{16}+\pi_{17} F_{t-1}+\pi_{18} X_{t}+\pi_{19} D_{t}+\pi_{20} K_{t}+\epsilon_{4 t}
\end{aligned}
$$

Comparing equations 12 and 13, we have:

$$
\pi_{16}=(m \alpha+\beta)(1+m v)^{-1} ; \text { and } \pi_{17}=\pi_{18}=\pi_{19}=\pi_{20}=m v(1+m v)^{-1}
$$

The reduced form of equations $1,2,3$ and 4 are represented by equations 11, 9, 6 and 13, respectively. The random components is assumed to be normally distributed with zero mean and constant variance.

$$
\begin{gathered}
Y_{t}=\pi_{11}+\pi_{12} F_{t-1}+\pi_{13} X_{t}+\pi_{14} D_{t}+\pi_{15} K_{t}+\epsilon_{3 t} \\
M S_{t}=\pi_{6}+\pi_{7} F_{t-1}+\pi_{8} X_{t}+\pi_{9} D_{t}+\pi_{10} K_{t}+\epsilon_{2 t} \\
F_{t}=\pi_{1}+\pi_{2} F_{t-1}+\pi_{3} X_{t}-\pi_{4} D_{t}+\pi_{5} K_{t}+\epsilon_{1 t} \\
M_{t}=\pi_{16}+\pi_{17} F_{t-1}+\pi_{18} X_{t}+\pi_{19} D_{t}+\pi_{20} K_{t}+\epsilon_{4 t}
\end{gathered}
$$

Following the arrangement of the small macro econometric model (1, 2, 3 and 4$)$, the four equations (11, 13, 6 and 9) have 20 reduced form coefficients, $\Pi_{1}-\Pi_{20}$. These coefficients are expressed as function of the four structural parameters $(v, m, \alpha$ and $\beta)$. Furthermore, $\epsilon_{1 t}, \epsilon_{2 t}, \epsilon_{3 t}$ and $\epsilon_{4 t}$ are emerging random disturbances associated with each of the reduced form equations. Relating the reduced form coefficients in each of the reduced form equations and structural parameter yield five unique equations $(14,15,16,17$ and 18) for identifying the four structural parameters.

$$
\begin{aligned}
& \pi_{1}=\frac{-(\beta+m \alpha)}{1+m v} \\
& \pi_{2}=\frac{1}{1+m v} \\
& \pi_{4}=\frac{-m v}{1+m v} \\
& \pi_{11}=\frac{(\alpha-v \beta)}{1+m v} \\
& \pi_{15}=\frac{v}{1+m v}
\end{aligned}
$$

Given that the number of unique equations is more than the number of structural parameters, it implies that the structural model is overidentified. Hence, in the spirit of Gujarati and Porter (2009), we employ TSLS, appropriate for overidentified equations in order to determine the four structural parameters required for understanding the link between domestic credit and balance of payments. The TSLS generates consistent estimates that are robust in the presence of specification errors. It also produces identical estimates as indirect least squares for exactly identified equation and the computational procedure generates accurate standard errors of estimates. 


\subsection{Estimation Procedure}

The estimation procedure starts with the examination of the descriptive and stationarity properties of the key variables. The study utilizes measures of central tendency and dispersion to evaluate the descriptive properties while relying on the famous augmented Dicky Fuller (ADF) and Philip Peron (PP) unit root techniques to determine the order of integration of individual series. Furthermore, the long run property of the variables in the balance of payment function is investigated using the Johansen technique. Then, the parameters of the four reduced form equations are estimated using the TSLS. The effect of domestic credit on BOP is determined from the statistical significance of the TSLS estimated reduced form parameter of the domestic credit in the balance of payment equation (equation 6). The structural parameters are recovered from the reduced form parameters algebraically. Finally, the effects of changes in domestic credit on economic activities and import are assessed from the values of structural parameters.

\section{Results and Discussion}

\subsection{Descriptive Results}

The results of relevant descriptive statistics covering measures of central tendency and dispersions, unit root test and cointegration are reported in this sub section. As indicated in table 1, domestic credit (D) appears to be more volatile than other variables while F remains the least volatile, as reflected in the values of standard deviation.

Table-1. Descriptive Statistics ${ }^{1}$

\begin{tabular}{l|l|l|l|l|l|l|l}
\hline Statistic & X & M2 & K & M & D & Y & F \\
\hline Mean & 3.07 & 15.32 & 0.55 & 2.27 & 14.53 & 19.00 & 0.04 \\
\hline Max & 5.10 & 27.07 & 1.13 & 4.10 & 27.68 & 33.36 & 0.06 \\
\hline Min & 1.45 & 4.80 & 0.27 & 0.60 & 0.54 & 7.77 & 0.02 \\
\hline Std. Dev. & 0.97 & 6.09 & 0.30 & 0.72 & 8.67 & 7.37 & 0.01 \\
\hline Obs & 48 & 48 & 48 & 48 & 48 & 48 & 48 \\
\hline
\end{tabular}

While assuming constant and constant $\&$ trend in the unit root specification, the ADF and PP unit root tests results are presented in table 2 . The variables appear to be stationary after first difference, with or without trend. From the two techniques, only capital inflows and GDP appear to be weakly stationary at 10\%, while other variables are stationary at $5 \%$ and $1 \%$ after first difference.

Table-2. Unit Root Test Results

\begin{tabular}{|c|c|c|c|c|c|c|c|c|}
\hline \multirow[t]{3}{*}{ Variables } & \multicolumn{4}{|c|}{ ADF t stats } & \multicolumn{4}{|c|}{ PP t stats } \\
\hline & \multicolumn{2}{|c|}{ Level } & \multicolumn{2}{|l|}{ 1st Diff. } & \multicolumn{2}{|l|}{ Level } & \multicolumn{2}{|l|}{ 1st Diff. } \\
\hline & C & C\&T & C & C\&T & C & C\&T & C & C\&T \\
\hline $\mathrm{X}$ & -1.34 & -1.65 & $-6.04 * * *$ & $-5.98 * * *$ & -1.42 & -1.80 & $-6.01 * * *$ & $-5.94 * * *$ \\
\hline M2 & 0.97 & $-3.72 * *$ & $-5.58 * * *$ & $-5.55 * * *$ & 0.96 & $-3.42 *$ & $-13.68 * * *$ & $-15.50 * * *$ \\
\hline $\mathrm{K}$ & -2.09 & $-3.40 *$ & $-2.61 *$ & -2.58 & -1.14 & -1.71 & $-2.71 *$ & -2.68 \\
\hline $\mathrm{M}$ & -1.18 & -2.33 & $-11.87 * * *$ & $-11.72 * * *$ & -2.39 & $-4.31 * *$ & $-12.22 * * *$ & $-12.05 * * *$ \\
\hline $\mathrm{D}$ & -0.61 & -2.29 & $-6.12 * * *$ & $-6.07 * * *$ & -0.62 & -2.29 & $-6.09 * * *$ & $-6.02 * * *$ \\
\hline $\mathrm{Y}$ & 1.65 & -0.65 & $-2.01 *$ & $-2.65^{*}$ & 2.70 & -0.28 & $-1.92 *$ & $-2.68 *$ \\
\hline $\mathrm{F}$ & -2.08 & -2.32 & $-4.36 * * *$ & $-4.32 * *$ & -1.79 & -1.91 & $-4.36 * * *$ & $-4.31 * *$ \\
\hline
\end{tabular}

$C$ and $C \& T$ indicates constant and constant \& trend, respectively. $* * *$, and $* * *$ signify level of significance at $10 \%, 5 \%$ and $1 \%$, respectively

Table 3 presents the cointegration results of the endogenous variables, while treating export, domestic credit and capital inflows as truly exogenous variables. Judging by the probability values, the trace statistic and Max-Eigen Statistic indicate two cointegrating equations (CEs) at the 0.05 level. This suggests a long run relationship of the variables in the system of equation, thus, giving credence to TSLS estimation of Polak model.

Table-3. Johansen Cointegration Test Result of the System

\begin{tabular}{l|l|l|l|l}
\hline No. of CE(s) & Eigenvalue & Trace Statistic & 0.05 Critical Value & Prob. Value \\
\hline None $*$ & 0.5645 & 73.2121 & 47.8561 & 0.0000 \\
\hline At most 1 $*$ & 0.373 & 34.9745 & 29.7971 & 0.0116 \\
\hline At most 2 & 0.1938 & 13.4983 & 15.4947 & 0.0978 \\
\hline At most 3 & 0.0751 & 3.5906 & 3.8415 & 0.0581 \\
\hline No. of CE(s) & Eigenvalue & Max-Eigen Statistic & 0.05 Critical Value & Prob. Value \\
\hline None $*$ & 38.23759 & 27.58434 & 0.0015 \\
\hline At most 1 & 0.5645 & 21.47614 & 21.13162 & 0.0447 \\
\hline At most 2 & 0.37304 & 9.90773 & 14.2646 & 0.2181 \\
\hline At most 3 & 0.19377 & 3.5906 & 3.84147 & 0.0581 \\
\hline
\end{tabular}

* denotes rejection of the hypothesis at the 0.05 level

\footnotetext{
${ }^{1}$ Variables are expressed in nominal terms and measured in trillions of Nigeria Naira

2 This amount to average of 4.72 or 472 per cent yearly. Interestingly, the 2018 CBN Annual Reports, page 136 has income velocity of money as $4.71,4.70,4.3,4.71$ and 4.72 for 2014, 2015, 2016, 2017 and 2018, respectively.
} 


\subsection{Empirical Results}

The summarised estimated results of reduced form equations 6, 9, 11 and 13 are presented in table 4. The estimated parameters are used to validate BOP as a monetary phenomenon and assess the reaction of GDP and total import to changes in domestic credit. In particular, the estimated coefficient of domestic credit is used to test the null hypothesis that the balance of payment is not a monetary phenomenon in Nigeria.

Table-4. Estimates of Reduced Form Models under the period of MPR MP Framework

\begin{tabular}{|c|c|c|c|c|}
\hline & $\begin{array}{l}\text { Foreign Reserves } \\
\text { Assets (F) }\end{array}$ & $\begin{array}{ll}\begin{array}{l}\text { Money } \\
\text { (MS) }\end{array} & \text { Supply } \\
\end{array}$ & Nominal GDP (Y) & Import (M) \\
\hline $\bar{C}$ & $\begin{array}{ll}0.005 & \\
(0.0037) & {[1.4702]}\end{array}$ & $\begin{array}{lll}0.695 & \\
(0.9189) & {[0.7563]}\end{array}$ & $\begin{array}{l}1.409 \\
(1.2172)\end{array}$ & $\begin{array}{lll}1.034^{\mathbf{c}} & \\
(0.3982) & {[2.5973]}\end{array}$ \\
\hline $\mathrm{F}(-1)$ & $\begin{array}{l}0.857^{\mathrm{a}} \\
(0.0694)\end{array}$ & $\begin{array}{l}64.363^{\mathrm{a}} \\
(17.3742) \quad[3.7045]\end{array}$ & $\begin{array}{l}59.76^{\mathrm{b}} \\
(23.0140)\end{array}$ & $\begin{array}{l}-13.754^{\mathrm{c}} \\
(7.5293) \quad[-1.8267]\end{array}$ \\
\hline $\mathrm{X}$ & $\begin{array}{l}0.00035^{\mathrm{c}} \\
(0.00025) \quad[1.4033]\end{array}$ & $\begin{array}{ll}0.686^{\mathrm{a}} & \\
(0.2168) & {[3.1661]} \\
\end{array}$ & $\begin{array}{l}0.913^{\mathrm{a}} \\
(0.2872) \quad[3.1795]\end{array}$ & $\begin{array}{ll}0.458^{\mathrm{a}} & \\
(0.0939) & {[4.8712]} \\
\end{array}$ \\
\hline $\mathrm{D}$ & $\begin{array}{l}-0.0002^{\mathrm{c}} \\
(-0.0001) \quad[-1.928]\end{array}$ & $\begin{array}{l}0.714^{\mathrm{a}} \\
(0.0215) \quad[33.2540]\end{array}$ & $\begin{array}{l}0.815^{\mathrm{a}} \\
(0.0284) \quad[28.6617]\end{array}$ & $\begin{array}{l}0.045^{\mathrm{a}} \\
(0.0093)\end{array}$ \\
\hline $\mathrm{K}$ & $\begin{array}{l}0.007^{\mathrm{b}} \\
(0.0037)\end{array}$ & $\begin{array}{l}-0.713 \\
(0.7622) \quad[-0.936]\end{array}$ & $\begin{array}{l}1.013 \\
(1.0097) \quad[1.0037]\end{array}$ & $\begin{array}{ll}-0.533 & \\
(0.3303) & {[-1.6132]}\end{array}$ \\
\hline R-sq & 0.88 & 0.98 & 0.98 & 0.77 \\
\hline D-W & 1.32 & 1.18 & 1.70 & 2.05 \\
\hline
\end{tabular}

For the balance of payment model, the predetermined variables (one period lag of foreign reserve assets, export, domestic credit and capital inflows) are statistically significant at various level. However, capital inflows is the only variable that is not significant in the monetary, growth and import functions. This is counterintuitive to investment and growth nexus, thus raising concern for foreign direct and portfolio investment strategy for the country.

Judging from the standard error of the estimate, domestic credit is found to be negatively related to foreign reserve assets and statistically significant at $10 \%$ level, meaning that the stated null hypothesis cannot be accepted. Thus, the significance of domestic credit in the balance of payment equation implies that balance of payment is a monetary phenomenon under the monetary policy framework in Nigeria. This result is consistent with the findings of Akpansung (1998) that reserve accumulation is negatively related to the rate of growth of domestic credit. Similar results can also be found in Tijani (2014), and Imoughele and Ismaila (2015). Furthermore, the established negative relationship supports Polak's formulation that an increase in domestic credit reduces the level of net foreign assets and balance of payments position. By implication, the monetary authority can manage disequilibrium in balance of payment by altering the growth path of domestic credit. But how will the adjustment in domestic credit affect economy? The following subsection provides the answer.

\subsection{Reaction of GDP and Total Imports to Changes in Domestic Credit}

To understand the impact of changes in domestic credit to other sector of the economy, we first recover the structural parameters by substituting the values of estimated reduced form coefficients in equations 14 to 18 . The value of $v$ is recovered from $\pi_{2}$ and $\pi_{15}$, while the value of $m$ is recovered from $\pi_{2}$ with the obtained value of $v$.

Thus,

and

$$
v=\frac{\pi_{15}}{\pi_{2}}=1.18
$$

From equation 18:

$$
m=\frac{1-\pi_{2}}{v \pi_{2}}=0.14
$$

$0.14 \alpha+\beta=-0.006$

$$
m \alpha+\beta=-\pi_{1}(1+m v)
$$

From equation 21:

$$
\alpha+1.18 \beta=1.642
$$

$$
\alpha+v \beta=\pi_{11}(1+m v)
$$

Combining equations 19 and 20, we apply Cramer's Rule to the matrix to obtain the values of $\alpha$ and $\beta$.

$\alpha=1.975$

$$
\left[\begin{array}{cc}
0.14 & 1 \\
1 & 1.18
\end{array}\right]\left[\begin{array}{l}
\alpha \\
\beta
\end{array}\right]=\left[\begin{array}{c}
-0.006 \\
1.642
\end{array}\right]
$$

At $1 \%$ level of significance, the standard error of the estimated coefficient of domestic credit in the output growth equation suggests that domestic credit has strong positive impact on output. The derived value of income velocity of money $(v)$ indicates that the speed at which money circulates in the economy is about 118 per cent, 
meaning that unit of domestic currency changes hand at least once in every quarter of the year ${ }^{2}$. In line with the monetarist view, this, to a large extent suggests that the monetary authorities seem to have a fair control of inflation. This can also be attributed to improved payment system and the financial inclusion drive in Nigeria.

Similarly, the standard error of the estimated coefficient of domestic credit suggests its marginal positive impact on output at $1 \%$ level. The impact of domestic credit on import through the growth in output is marginal as the marginal propensity to import in relatively low at 14 per cent compared to 20 per cent obtained by Ajibola and Nwakanma (2013). Among other factors, this could be attributed to strict indirect import restrictions policies embarked upon under the current monetary policy program such as the ban on forex sales through the Central Bank forex window for items that have potentials for domestic production.

Thus, the estimated Polak model for Nigeria can be represented as:

$$
\begin{gathered}
\widehat{Y}_{t}=1.975+1.18 M S_{t} \\
\widehat{M}_{t}=-0.2822+0.14 Y_{t} \\
F_{t}=F_{t-1}+X_{t}-M_{t}+K_{t} \\
M S_{t}=D_{t}+F_{t}
\end{gathered}
$$

In summary, a unit change in money supply as a result of change in domestic credit, while keeping foreign assets reserve unchanged will lead to about 1.2 units change in nominal GDP. In addition, a unit change in nominal GDP as a result of change in money supply induced by change in domestic credit will cause about 0.14 -unit change in import.

\section{Summary Conclusion and Recommendations \\ 5.1. Summary and Conclusion}

This study examines the validity of monetary approach to balance of payment as well as the implication of changes in domestic credit on overall economic activities and total import under the current monetary framework in Nigeria. The study follows the Polak (1997), Polak (1957) model. The model consists of two structural equations for aggregate demand and import and two equilibrium conditions for monetary and external sectors. The structural form of the model represents hypotheses about the Nigeria economic structure that increase in domestic credit is assumed to affect aggregate demand and total imports.

The study period covers the current monetary policy framework from 2007:Q1 to 2018:Q4. Using Johansen cointegration procedure, the study examines the long run relationship of the variables in the balance of payment equation. Due to inadequacies of OLS in estimating the structural parameters of the system as a result of simultaneity, the TSLS is employed to determine reduced form parameters. The MABOP is validated based on the statistical significance of domestic credit in the reduced form balance of payment equation. The structural parameters are recovered from the reduced form parameters algebraically; and the effects of changes in domestic credit on economic activities and import are assessed from the values of structural parameters.

The results of the study are enriching and robust. The trace and Max-Eigen Statistic suggests a long run relationship among the variables in the balance of payment equation. The predetermined variables in the balance of payment equation are statistically significant. Specifically, domestic credit is found to be negatively related to foreign reserve assets and statistically significant, confirming that balance of payment is a monetary phenomenon in Nigeria. However, capital inflows appear statistically insignificant in the monetary, growth and import functions. This is counterintuitive to investment and growth nexus, thus posing a significant implication for foreign direct and portfolio investment strategy for the country. The speed at which money circulates in the economy is about 118 percent, implying that the monetary authorities seem to have a fair control of inflation with the current monetary policy framework. At 14 per cent, the marginal propensity to import is relatively low compared to 20 per cent obtained by Ajibola and Nwakanma (2013), which could be attributable to the strict indirect import restrictions policies embarked upon under the current monetary policy program such as the closure of access to forex through the Central Bank window for items that have potentials for domestic production. Finally, the study shows that a unit change in money supply as a result of change in domestic credit leads to about 1.2 units change in nominal GDP, while a unit change in nominal GDP causes about 0.14-unit change in import. This information is significant for macroeconomic policy decision.

\subsection{Recommendations}

With the established long run relationship among the macroeconomic variables, and also given the significance of domestic credit in the balance of payment equation (that is, validity of monetary approach to balance of payment), it becomes pertinent for the monetary authorities to consider the use of domestic credit for long run adjustment of current account deficit or balance of payment disequilibrium.

The impact of changes in money supply on income is higher than the impact of changes in income on import caused by changes in domestic credit. Thus, there is need for scaling up domestic credit either through low monetary policy rate or special intervention in key priority sectors to grow the economy. Given the fraction of marginal propensity to import, such action will marginally decrease external reserve assets through increase in import, however, with the level of money velocity, the economy will be better.

\footnotetext{
${ }^{2}$ This amount to average of 4.72 or 472 per cent yearly. Interestingly, the 2018 CBN Annual Reports, page 136 has income velocity of money as 4.71, 4.70, 4.3, 4.71 and 4.72 for 2014, 2015, 2016, 2017 and 2018, respectively.
} 
Finally, the monetary authority should sustain the policy that restricts forex sales for the importation of items that can be produced locally to encourage import substitution and boost local production, thereby reducing the pressure on the current account component of the balance of payment.

\section{References}

Ajibola, A. and Nwakanma, P. C. (2013). Money supply and velocity of money in nigeria: a test of polak model. Journal of Management and Sustainability, 3(4): 136-50.

Akonji, D. R. and Olateju, A. O. (2013). The impact of monetary policy on current account balance in Nigeria. Journal of Humanities and Social Science, 7(3): 67-72.

Akpansung, A. O. (1998). Applicability of monetary approach to Nigeria's balance of payments, $1960-1995$. Unpublished M.Sc (Economics) Thesis, University of Calabar, Nigeria.

Akpansung, A. O. (2013). A review of empirical literature on balance of payments as a monetary phenomenon. Journal of Emerging Trends in Economics and Management Sciences, 4(2): 124-32.

Alexander, S. S., 1952. "Effects of devaluation on trade balance." In International Monetary Fund Staff Papers, II.

Argy, V. (1969). Monetary variables and the balance of payments. International monetary fund. Staff Papers. Palgrave Macmillan Journals: 267-88. Available: https://www.jstor.org/stable/3866435

Boateng, C. and Ayentimi, D. T. (2013). An empirical analysis of balance of payment in Ghana using the monetary approach. European Journal of Business and Management, 5(8): 11.

Bobai, F. D. (2013). An empirical analysis of the balance of payments as a monetary phenomenon: Nigeria's experience. Journal of Emerging Issues in Economics, Finance and Banking, 1(2): 107-27.

CBN (2015). Central bank of Nigeria annual report.

CBN (2016). Central bank of Nigeria annual report.

Connolly, M. and Taylor, D. (1979). Testing the monetary approach to devaluation in developing countries. Journal of Political Economy, 124(3): 849-60.

Dornbusch, R. (1971). Notes on growth and the balance of payments. Canadian Journal of Economics, 4: 389-95.

Faiz, B. (1989). Monetary approach to balance of payments: the evidence on reserve flow from Pakistan. The Pakistan Development Review, 28(3): 195-206.

Fleermuys, F. N., 2005. "The balance of payments as a monetary phenomenon: An econometric study of Namibia." In Dea Research Discussion Paper.

Gujarati and Sangeetha (2007). Basic econometrics. Tata McGraw Hill Publishers: New Delhi.

Gujarati and Porter, D. (2009). Basic econometrics.

Gulzar, A. (2015). Pakistan's balance of payments as a monetary phenomenon: Econometric evidence. Journal of Managerial Sciences, 5(2): 7.

Imoisi, A. I., Olatunji, L. M. and Ekpenyong, B. I. (2013). Monetary policy and its implications for balance of payments stability in Nigeria: 1980-2010.

Imoughele, L. E. and Ismaila, M. (2015). Monetary policy and balance of payments stability in Nigeria. International Journal of Academic Research in Public Policy and Governance, 2(1).

Jimoh, A. (1990). The monetary approach to balance of payments: Evidence from Nigeria. Africa Economic Review, 6(1): $69-75$

Johnson, H. G. (1977). The monetary approach to balance of payments theory and policy: Explanation and policy implications. Economica, New Series, 44(175): 217-29.

Johnson, H. G. and Frenkel, J. A. (1976). The monetary approach to the balance of payments, eds.

Kavous, A. (2005). The monetary approach to balance of payments: a review of the seminal long-run. Empirical Research Journal of Economics and Economic Education Research, 6(1).

Koutsoyiannis, A. (1977). Theory of econometrics. 2nd edn: Macmillan Publishers: London.

Meade, J. E. (1951). The theory of international economic policy. Volume $i$ : The balance of payments. Macmillan: London.

Melvin, M. (1992). International money and finance. 3rd edn: Harper Collins Publishers Inc: New York.

Mukolu, M. O., Illugbemi, A. O. and Otalu, J. A. (2017). Monetary policy and its implication for balance of payment stability in Nigeria between 1986-2015. Asian Journal of Economic Modelling, 5(4): 480-92.

Mundellr, A. (1968). International economics. Macmillan: London.

Mushendami, P., Manuel, V., Shifotoka, H. and Nakusera, F. (2017). Empirical analysis of the monetary approach to the balance of payment in Namibia. International Review of Research in Emerging Markets and the Global Economy, 3(1): 1088-104.

Negishit, T. (1968). Approaches to the analysis of devaluation. International Economic Review, 9(2): 218-27.

Nyong, M. O. and Obafemi, F. N. (1995). Exchange rate policy and macroeconomic adjustment in Nigeria: a theoretical and empirical analysis with policy implication. Journal of Economic Studies, 1(1).

Onuchuku, O., Chukueggu, C. C., Nenbee, S. G. and Wosu, C., 2018. "Monetary policy and Nigeria's balance of payments." In Proceedings of ISER 128th International Conference, New York, USA, 16th-17th May 2018.

Osisanwo, B. G., Tella, S. A. and Adesoye, B. A. (2019). The empirical analysis of monetary policy on balance of payments adjustments in Nigeria: A bound testing approach. Iran. Econ. Rev. , 23(1): 129-47.

Polak, J. J. (1957). Monetary analysis of income formation and payments problems. IMF Staff Papers, 6: 1-50.

Polak, J. J. (1997). The IMF monetary model, a hardy perennial. Finance and Development, IMF.

Proso, T., Inaya, L. S. and Okoye, E. I. (2016). Monetary policy and balance of payments in Nigeria. 
Pyndyck, R. S. and Rubinfeld, D. L. (1976). Econometric models and economic forecasts. McGraw-Hill Publishers: New York.

Salvatore, D. (2004). International economics. John Wiley and Sons (Asia) Pte Ltd.

Stock, J. H. and Watson, M. W. (1993). A simple estimator of cointegrating vectors in higher order integrated system. Economometrica, 61: 783-820. Available: http://dx.doi.org/10.2307/2951763

Taiwo, I. O. (1991). An assessment of the balance of payments crisis in Africa using bayesian posterior-odds ratio. Nigerian Journal of Economic and Social Studies, 34(1): 31-40.

Tijani, J. O. (2014). Empirical analysis of balance of payment adjustment mechanisms: monetary channel in Nigeria. Mediterranean Journal of Social Sciences MCSER Publishing, Rome-Italy, 5(1): 67-76.

Udude, C. C. (2015). Monetary policy and balance of payment in Nigeria (1981-2012). Journal of Policy and Development Studies, 9(2): 14-26.

Wooldridge, J. (2003). Introductory econometrics: A Modern Approach. 2nd edn: Thomson/South-Western: Ohio. 